\title{
Associated work in a cooperative is neither dependent work nor self- employed work
}

\section{Gemma Fajardo García}

ABSTRACT: The celebration of the 100th anniversary of the ILO's Cooperatives Unit sparked interest in reviewing the progress made by this institution in relation to the recognition and promotion of worker cooperatives. To this end, the Promotion of Cooperatives Recommendation (2002) and the Guidelines concerning statistics of Cooperatives (2018) were taken as the focus of study. From the analysis of both documents, the conclusion was drawn that although the former calls for the recognition of cooperatives in the terms established by the ICA, and for their promotion by States, establishing a legal framework favourable to them and compatible with their nature as self-managed enterprises, the fact is that associated work is still not recognised as a mode of work distinct from dependent work (wage-based) and self-employed (individual) work. This lack of recognition does not correspond to the recommendations of the ICA (2005) claiming that "the relationship of the worker-member with their cooperative should be considered as distinct from that of conventional wage-based dependent work and self-employed work". The lack of recognition is often attributed to the modest size of these cooperatives and their possible use to circumvent the application of labour law. However, as we have shown, the former cannot be proven, and the latter is not sufficient reason to ignore or prohibit them, since there are other means to combat fake cooperatives. The lack of a contractual relationship between the worker-member and the cooperative is not a weakness but a strength and is the result of having a specific legal type for the cooperative, as opposed to other countries such as France or Italy which, because they lack such a type, are incorporated as Public Limited Companies or Limited Liability Companies, and subsequently hire their members so that they can work in their company.

KEYWORDS: Workers' cooperative, associated work, cooperative law, ILO, ICA.

ECONLIT DESCRIPTORS: K20, K31, L26, L30, M50, M54. 
How to cite this article: FAJARDO, G. (2021): "Associated work in a cooperative is neither dependent work nor self-employed work", CIRIEC-España, Revista de Economía Pública, Social y Cooperativa, 103, 315-335. DOI: 10.7203/CIRIEC-E.103.20685.

Correspondence: Gemma Fajardo García, IUDESCOOP-University of Valencia, Isabel.Fajardo@uv.es.

RESUMEN: La celebración del centenario de la Unidad de Cooperativas de la OIT nos suscitó el interés de revisar los avances realizados por esta institución en relación con el reconocimiento y fomento de las cooperativas. A tal fin se tomó como eje de estudio la Recomendación sobre la promoción de las cooperativas (2002) y las Directrices sobre estadísticas cooperativas (2018). De la conjunción de ambos documentos se extrajo la conclusión de que a pesar de que el primero reclama que se reconozcan las cooperativas en los términos fijados por la ACI, y que se promuevan por los Estados, estableciendo un marco jurídico favorable a las mismas y compatible con su naturaleza como empresa auto-gestionada, lo cierto es que sigue sin reconocerse el trabajo asociado propio de las cooperativas, como una modalidad diferente al trabajo dependiente (asalariado) y al trabajo autónomo (individual). Esta falta de reconocimiento no se corresponde con la recomendación de la ACI (2005) según la cual "la relación del socio trabajador con su cooperativa debe ser considerada como distinta a la del trabajo asalariado dependiente convencional y a la del trabajo individual autónomo". La falta de reconocimiento suele atribuirse a la modestia de estas cooperativas, y a su posible uso para burlar la aplicación del derecho del trabajo. Sin embargo, como hemos puesto de manifiesto ni puede acreditarse lo primero, ni lo segundo es razón suficiente para ignorarlas o prohibirlas, existiendo otros medios para combatir las falsas cooperativas. La falta de relación contractual entre el socio trabajador y la cooperativa no es una debilidad sino una fortaleza, y es consecuencia de disponer de un tipo jurídico específico para la cooperativa, a diferencia de otros países como Francia o Italia que, por carecer del mismo, se deben constituir como sociedades anónimas o sociedades de responsabilidad limitada, y posteriormente contratan a sus socios para que puedan trabajar en la sociedad.

PALABRAS CLAVE: Cooperativa de trabajadores, trabajo asociado, derecho cooperativo, OIT, ACI. 


\section{Resumen amplio}

\section{El trabajo asociado en cooperativa no es trabajo dependiente ni autónomo}

En 2020 se celebró el centenario de la Unidad de Cooperativas de la OIT. Este acontecimiento era una buena ocasión para preguntarse por la contribución de la OIT al desarrollo del cooperativismo entre los trabajadores, y en particular sobre la postura de la organización en relación con las cooperativas de trabajo asociado.

Para llevar a cabo este análisis hemos tenido en cuenta el origen del interés de esta organización por las cooperativas, las principales decisiones adoptadas en torno a las mismas y los estudios existentes en particular en torno a las cooperativas de trabajadores, y en especial los promovidos o apoyados por esta organización. También hemos analizado otros estudios realizados a nivel internacional y una selección de la principal bibliografía que desde un punto de vista jurídico se ha ocupado de la cuestión.

Las declaraciones de la OIT analizadas han sido principalmente la Recomendación sobre la promoción de las cooperativas de 2002 y la Directrices sobre estadísticas cooperativas de 2018.

La estructura del trabajo se divido en 9 apartados, al margen de la Introducción y las Conclusiones. En el primero se indaga en las motivaciones que llevaron a la OIT a crear la Unidad de Cooperativas. El segundo se centra en la Recomendación de la OIT sobre la promoción de las cooperativas y en particular en el mensaje dirigido a los gobiernos para que conciban las cooperativas conforme a la definición, valores y principios de la ACI, y establezcan un marco jurídico favorable a aquellas y compatible con su naturaleza y función. En el tercer apartado hemos puesto de relieve la diversidad de marcos jurídicos existentes en Europa para las cooperativas consecuencia de su diversa naturaleza, mutualista, asociativa o societaria. El cuarto apartado parte de la existencia de diversas clases de cooperativas según cual sea la función de sus socios, como productores o consumidores, para acabar centrando su atención en las cooperativas de trabajo asociado. Este modelo de cooperativa, con diversas denominaciones se ha expandido principalmente por el sur de Europa y por América Latina. Precisamente la Ley Marco para las Cooperativas de América Latina de 2009 nos ofrece una completa definición de este tipo de cooperativas. El quinto apartado ha analizado las principales características de estas cooperativas, según la Declaración aprobada por la Asamblea General de la ACI en 2005 sobre Cooperativismo de Trabajo Asociado. El sexto apartado se ha dedicado a las Directrices sobre estadísticas cooperativas, con las que la OIT pretende contabilizar a nivel mundial la creación de empleo y de actividad económica. El análisis de este documento y de los estudios previos ponen de manifiesto la falta de reconocimiento del trabajo asociado como característico de las cooperativas, al no contemplar más que cooperativas de trabajadores dependientes o cooperativas de trabajadores autónomos. En el apartado séptimo hemos recurrido a la Carta 
del Trabajador Autogestionario elaborada por los miembros de una asociación internacional de investigadores en la materia, y que reivindican la especialidad del trabajo asociado como un modelo diferente a los anteriores y propio de las citadas cooperativas. El apartado octavo se centra en otra cuestión jurídica controvertida, ¿tiene el socio trabajador una relación asociativa o contractual con la cooperativa de trabajo asociado?, la respuesta no es única, sino que depende de la diversa naturaleza jurídica de la cooperativa en los diversos países, pero no puede excluirse la relación societaria, cuando está presente en la mayor parte de los países y además reconocida en las legislaciones. Dado que la razón principal por la que se reivindica la relación contractual y laboral entre socios trabajadores y cooperativas, es evitar situaciones fraudulentas, hemos querido dedicar el apartado noveno precisamente a la cuestión de la utilización fraudulenta de las cooperativas de trabajo asociado, para tratar de demostrar que estas prácticas fraudulentas deben ser combatidas por otros medios, no desconociendo o prohibiendo las cooperativas de trabajo asociado.

\section{Introduction 1}

In 2020, the 100th anniversary of the ILO's Cooperatives Unit was celebrated. This event was a good opportunity to review the contribution made by the ILO to the development of worker cooperatives and, in particular, the institution's stance in relation to associated work cooperatives.

In order to carry out this analysis, we have taken into account the aspects that originally led the institution to form an interest in cooperatives, the main decisions taken by it in relation to them, and existing studies specifically related to worker cooperatives, especially those that are promoted and supported by this institution. We have also analysed other studies carried out internationally and a selection of the main reference literature that, from a legal standpoint, has dealt with this issue.

The ILO's resolutions analysed are mainly the Promotion of Cooperatives Recommendation (2002) and the Guidelines concerning statistics of Cooperatives (2018).

The study is divided into 9 sections, in addition to the Introduction and Conclusions sections. In the first section, the reasons that led the ILO to create the Cooperatives Unit are explored. The second section focuses on the ILO's Promotion of Cooperatives Recommendation and, specifically, on the message aimed at governments in order for them to conceive cooperatives in accordance with the definition, values and principles of the ICA and for them to establish a legal framework that is favourable to cooperatives and compatible with their nature and role. In the third section, we highlight the diversity of existing legal frameworks in Europe

1. This paper expands upon the presentation given by the author, with the same title at the ILO COOP 100 Symposium held on 16-17 November 2020 and is the result of the research project: $R+D+i$ Project: Social Economy, Self-Management and Employment (DER2016-78732- R), funded by the Ministry of Science, Innovation and Universities of Spain, State Research Agency and European Regional Development Fund (ERDF). 
for cooperatives as a result of their diverse nature as mutual-aid societies, associated work cooperatives and corporations. The fourth section draws on the existence of various types of cooperatives according to the role of their members, as producers or consumers, and finishes by focusing on associated work cooperatives. This type of cooperative, which has adopted several different names, has mainly spread throughout Southern Europe and Latin America. In fact, the Framework Law for Cooperatives in Latin America (2009) provides a full definition of this kind of cooperative. The fifth section analyses the main features of these cooperatives, according to the Declaration on Worker Cooperatives approved by the ICA General Assembly in 2005. The sixth section is dedicated to the Guidelines concerning statistics of Cooperatives, with which the ILO intends to account for the creation of employment and economic activity on a global scale. The analysis of this document and of previous studies highlights the lack of recognition of associated work as being a characteristic feature of cooperatives, given that the document does not account for more than dependent worker cooperatives or selfemployed worker cooperatives. In the seventh section we refer to The Charter of the SelfManaged Worker drafted by members of an international association made up of researchers who study the topic and who assert that the area of associated work is a different model to the previous ones and that it is unique to the aforementioned cooperatives. The eighth section focuses on another controversial legal issue, asking the question "Does the worker-member have an associative or contractual relationship with the associated work cooperative?". There is no single answer to this, as it depends on the diverse legal nature of the cooperative in different countries, but the corporate relationship must not be excluded when it is present in the majority of countries and is also recognised in legislation. Given that the main reason for asserting a contractual and employment relationship between worker-members and cooperatives is to avoid fraudulent situations, we have dedicated the ninth section precisely to the issue of fraudulent use of associated work cooperatives in order to try to show that these fraudulent practices must be combated by other means, not by disregarding or banning associated work cooperatives.

\section{The ILO and Cooperatives}

In 2020, the 100th anniversary of the creation of the ILO's Cooperatives Unit was celebrated, an anniversary that brought together various activities around this organisation and cooperatives. In fact, on 23 March 1920, the Section of Co-operation was formally constituted at the proposal of the then ILO Director Albert Thomas. The reason stated was to promote cooperation among workers in order to improve their living conditions (food, housing, leisure) ${ }^{2}$. At that time, no mention was made of the cooperative as a means of promoting the collective self-employment of workers.

2. https://www.ilo.org/public/libdoc/ilo/P/09601/09601(1920-2).pdf 
Since then, the ILO has carried out several actions in relation to cooperatives, especially in the field of training, an area for whose development it created the International Training Centre (ITC-ILO) in 1964. This centre offers technical and professional training programmes with the aim of achieving decent work for all women and men, as stated in its about page ${ }^{3}$.

For the purposes of the subject matter of this paper, we are interested in highlighting the 2002 Promotion of Cooperatives Recommendation ${ }^{4}$, and the 2018 Guidelines concerning statistics of Cooperatives, among other aspects ${ }^{5}$.

\section{ILO Recommendation on the Promotion of Cooperatives}

The 2002 Recommendation conceives the cooperative in accordance with the definition, values and principles of the 1995 International Cooperative Alliance (ICA) Statement on the Cooperative Identity and sets out a series of recommendations addressed to governments, employers, workers and cooperative organisations of all ILO Member States, in order to promote cooperatives, whatever their type, as well as to support their members (H. Henrÿ, 2013:58).

This recommendation identifies the cooperative as an autonomous association of persons

united, voluntarily, to meet their common economic, social and cultural needs and aspirations, through a jointly owned and democratically managed enterprise (paragraph 1). Likewise, it recommends governments to establish a legal framework favourable to cooperatives, compatible with their nature and function, to encourage the development of cooperatives as autonomous and self-managed enterprises, and to ensure that labour legislation applies to all enterprises (Henrÿ, 2016:37),

\section{The establishment of a favourable legal framework for cooperatives}

Achieving a favourable legal framework that is compatible with the nature of cooperatives is a challenge for States. Not all States recognise the cooperative as a type of business organisation and, among those that recognise it and endow it with legal personality, some have chosen to create their own organisational model adapted for cooperatives as is the case in Germany or Spain, while in other States cooperatives must be constituted as associations (Holland) or civil

3. https://www.itcilo.org/about

4. Recommendation No. 193 on the Promotion of Cooperatives. International Labour Conference. Geneva, 2002.

5. Guidelines concerning statistics of Cooperatives. 20th International Conference of Labour Statistics, Geneva, 10-19 October 2018. 
or commercial companies, (France or Italy), to which certain particular rules apply, which are typically inspired by cooperative principles (Münkner, 2015: 17; Espagne, 2001).

Let us recall that, when it was formed in 1844, the Rochdale Equitable Pioneers Cooperative, in the absence of a legal framework of its own, took the statutes of a mutual benefit society, the Manchester Sick and Burial Benefit Society (Holyoake), as a reference. Possibly, they felt closer to a society based on mutual aid, open doors and democratic management than to a society created to generate distributable profits. English cooperatives were regulated as Friendly Societies until 1852 when a separate law was passed for them, the Industrial and Provident Societies Act (Cracogna, 2015).

In the case of Spain, the cooperatives that were constituted throughout the 19th century had to do so by adopting one of the legal structures permitted at that time (mainly association, professional partnership and limited company) and it was not until 1931 that they had their own legal statute, which included their purposes, values and behavioural guidelines. As of the Law of 9 September 1931, those who wanted to constitute an entity as a cooperative had to adopt the new legal structure created for it and which guaranteed that they could comply with its purposes and principles. Those already existing had to register in the Cooperatives Registry or stop using this title (Polo, 1942:215). The cooperative society is defined in this law as an association of natural persons or legal entities, whose organisation and operation are subject to the requirements of said law and moving towards removing profit, whose purpose is to satisfy a common need, seeking the social and economic improvement of the associates through their joint action in collective work (Art. 1). Next, the legal conditions necessary to become a cooperative (Art. 2) were set forth, and further on, rules were established to facilitate their organisation and operation.

\section{Types of Cooperatives and Worker Cooperatives}

The people who join a cooperative may have different needs and aspirations, and depending on which of these prevail, different types of cooperatives can be distinguished. The reference to the "cooperative" is made in formal terms ${ }^{6}$. A basic classification makes it possible to distinguish between producer cooperatives, consumer cooperatives and hybrid cooperatives, depending on the role played by the cooperative in the market, either as a supplier of goods and services produced by its members, or as a purchaser of goods or services for its members. The Handbook on Cooperatives for use by Workers' Organizations (Tchami, 2007) differentiates between service cooperatives and worker cooperatives according to the main objective pursued

6. We are aware that in some places they label enterprises controlled and developed by the people who work in them as "worker cooperatives", which may be organised as associations, for profit or non-profit entities, or formally as cooperatives (Ellerman, 1984). 
by cooperative members. But we can also differentiate, according to the condition in which the members act, between worker cooperatives, business or professional cooperatives (which can be both producers and consumers), end consumers or users, and hybrid cooperatives.

So-called worker cooperatives are production cooperatives because they provide goods and services to the market, but they are specifically worker cooperatives because those goods and services are the fruit of the labour of their members (individuals). As Jean-Philippe Buchez, creator of the first associated work cooperative, said "Men associate their work, not their capital" (Monzón, 1989:43). In fact, in worker cooperatives, workers associate with each other to, with their mutual support, start up an economic activity that allows them to generate and maintain their own jobs, and to do so under the best possible conditions. The name associated work cooperative highlights the manner in which the work is provided in the cooperative; worker-members do not work for themselves or for others, they work by associating their work to that of their colleagues, supporting each other and using the cooperative as a tool for coordination and relationship with the market, to which they offer their products and services $^{7}$. The expression "associated work cooperative", although it is a very widespread name, is not the only one used to name the cooperative formed by people who join forces to work together.

In France, these cooperatives are known as sociétés coopératives de production, and may be called sociétés coopératives de travailleurs, or sociétés coopératives ouvrières de production; in Portugal, Cooperativas de Produção Operária, in Italy, Cooperative di Produzione e Lavoro, and in Greece and Japan, worker cooperatives.

In Spain, they were initially known generically as producers' cooperatives and later, as worker cooperatives (Torres, 2016). From the 1970s onwards, this type of cooperatives reached an important point; on the one hand, due to their usefulness in the face of the business crisis and the increase in unemployment (Fernández de la Gándara, 1986), and on the other hand, due to the impulse of the new Law 52/1974, General Law of Cooperatives. This law classifies these cooperatives as worker cooperatives for the first time (Valdés Dal-Re, 1975).

This term is also used to identify this cooperative model in most Spanish- and Portuguese-speaking countries ${ }^{8}$. In fact, the Framework Law for Cooperatives in Latin America, drafted by a Commission of Experts ${ }^{9}$ and edited in 2009 by the International Cooperative Alliance ${ }^{10}$, dedicates its Section 91 to Cooperatives of associated work, and defines them as "those in which the members are linked to satisfy their need for work through activities of production of goods or provision of services organised directly by the cooperative, which must be the owner or holder of the

7. As has also been highlighted: "A worker cooperative is a form of organisation for the employment of a group of workers who are associated with one another for working together and joint reward by doing business activities" (Sapovadia \& Patel, 2013)

8. Numerous studies have been carried out by legal academic opinion on associated work cooperatives and, in particular, on the relationship between the member and the cooperative.

9. Committee composed of Professors Dante Cracogna (Coordinator of the Commission and representative of the Southern Cone); Roxana Sánchez (Representative of Central America and the Caribbean); Belisario Guarín (Representative of the Andean Area), and the collaboration of Hagen Henrÿ (Chief of the Cooperative Service of the ILO). 10. https://www.aciamericas.coop/Framework-Law-for-the-Cooperatives 
means of labour, with technical and entrepreneurial autonomy, without acting as a labour intermediary. Membership shall be limited to the existence of an office or position to perform the work".

\section{Characteristics of Worker Cooperatives}

The World Declaration on Worker Cooperatives, approved by the ICA General Assembly in 2005, differentiates three modalities in which the work activity can be carried out: a) as self-employed work; b) as wage-based dependent work, under the subordination of an employer, or c) as associated work, where work and management are carried out jointly, without the limitations of individual work or exclusively under the rules of wage-based dependent work.

Associated work is not only found in cooperatives, but also in other forms of organisation, associations, professional partnership and sole proprietorships, in which the members contribute their labour and in exchange receive a share in the profits and enjoy other social and political rights, such as the right to vote (Vergez, 1972); however, as the ICA states, among the modalities of associated work, that organised by cooperatives is the most important in the world.

The 2005 ICA Declaration states that worker cooperatives must be governed in accordance with the principles and values contemplated in the Statement on the Cooperative Identity (Manchester, 1995), but it is also necessary to define some basic characteristics and internal operating rules on a global level that are specific to this type of cooperative, since they have specific aims and purposes, distinct from those of other cooperatives. This would be the case, for example, of artisans' cooperatives, which are also members of CICOPA (International Organisation of Industrial and Service Cooperatives). Therefore, the Declaration is addressed only to worker cooperatives, without prejudice to its use by other workers' organisations.

The Declaration cites the following as some of the characteristics of worker cooperatives: a) they aim to create and maintain sustainable jobs, generating wealth to improve the quality of life of worker-members, dignify human labour, allow workers' democratic self-management and promote community and local development; b) the free and voluntary membership of their members is conditional on the existence of workplaces; c) as a general rule, the work shall be carried out by the members, which implies that the majority of the cooperative's workers are members and that the majority of the members are workers; d) their internal regulation is governed by resolutions democratically adopted and accepted by all worker-members, e) they must be autonomous and independent before the State and third parties, and f) "The relationship of the worker-member with their cooperative must be considered as distinct from that of conventional wage-based work and self-employed work".

The above Declaration also offers some rules that worker cooperatives must take into account in their internal functioning, related to the compensation of the work of their members 
(according to their function, responsibility, complexity, speciality, productivity and economic capacity, trying to reduce the difference between the highest and lowest compensations); the strengthening of the cooperative through the constitution of reserves and irreparable funds; the protection of worker-members with adequate welfare and social security systems among others; the practice of democracy; the education and continuous training of members; improving the living conditions of members' families; contributing to the sustainable development of their communities, and combating their being instruments aimed at making the working conditions of wage-based workers more flexible or precarious, not acting as intermediaries in the provision of jobs.

\section{Guidelines concerning statistics of Cooperatives}

The other action that we wanted to highlight from the ILO is the approval in October 2018 of the Guidelines concerning statistics of Cooperatives, which aim to globally account for the contribution of cooperatives to job creation and economic activity. This accounting takes into account the workers, whether or not they are members of the cooperatives and regardless of the type of cooperative in which they work or for which they work ${ }^{11}$.

For these purposes, the study uses the International Standard Classification of Occupations (ISC0-18), approved on the same dates by ILO Resolution of 17 October 2018. This system classifies worker-members of cooperatives as "Dependent Workers", a category that in turn is composed of two sub-categories: dependent contractors and employees. ${ }^{12}$.

The classification criteria (ISCO-18) are based on the type of economic risk and the type of authority.

A) Depending on the type of economic risk, i.e. exposure to loss of financial resources and uncertainty about remuneration for work performed, the system differentiates between:

a) Workers employed in return for remuneration for time or the task performed, and

b) Workers employed for profit, which entails a risk of loss as well.

B) Depending on the type of authority or control that the worker has over the organisation of their work, the system differentiates between:

a) Self-employed workers, identified as those who own and control (individually) the enterprise in which they work, and

11. The failure to differentiate between member and non-member workers of cooperatives reduces the validity of the studies conducted by the ILO, as we already criticised at the time, especially when it is intended to extract qualitative characteristics of the work carried out in cooperatives (Fajardo, 2018).

12. Regarding the difficulty of being able to provide statistical information on cooperative modes of employment, the international classification criteria and the methodology to be used, see Eum (2017). 
b) Dependent workers, who are the most important decision-makers in the company in which they work. These dependent workers may in turn be, as it says: dependent contractors or employees.

(b-1) Dependent contractors are individual entrepreneurs who have a contract of a commercial nature for the supply of goods or services (transport contract, agency contract, etc.) with another businessperson, but do not have much autonomy in organising their activity, and their income depends for the most part on this relationship. This worker is recognised in Spain as a "financially dependent self-employed worker" (TRADE) and has a specific legal provision in Chapter III of Law 20/2007 which regulates the Statute of the Self-Employed Worker).

(B-2) Employees are those who have an employment contract, are employed in return for remuneration for time or the work performed, and do not have a controlling interest in the enterprise that employs them. The Guide includes "worker-members of cooperatives who are remunerated on a time-based, task-based or unit-based basis" in this category.

According to the criteria used for the creation of the Guidelines, and taking into account the regulation of worker cooperatives, it could be said that worker-members of these cooperatives provide their work in exchange for profits, although they may receive advances on account of profits, for an amount equivalent to the amount established by the collective agreement for wage-based workers. It may also be affected by losses if the final result for the financial year is negative, unless the cooperative has sufficient reserves to offset them ${ }^{13}$. As for the control that worker-members have in the cooperative, they all have the right to information, the right to speak and the right to vote; they are electors and are eligible for the cooperative's social security contributions; they have the capacity to propose issues for debate and make proposals for resolutions, as well as to challenge corporate resolutions, revoke directors or hold them accountable. Laws usually reserve the most important decisions to the Members' General Meeting, including deciding the general policy of the cooperative and determining the rights and obligations of all members. Most of these are individual rights of every worker-member, while others require the agreement of a minimum number of members to be exercised. Finally, worker-members assume the right and duty to work as a member, without having to enter into an employment or collaboration contract with the cooperative.

Ultimately, the choice between dependent workers or self-employed workers does not cover the full spectrum of possible employment relationships ${ }^{14}$, and the Guidelines certainly do

13. Conversely, Hyungsik Eum (2020:27) argues that by calculating the advance payment "by pooling the income from all activities carried out through the cooperative, the advance payment is also a way of ensuring a certain level of job security and income so that it can be considered as "payment" rather than "profit". However, the advance payment is paid on the basis of the income generated exclusively by the members' work, without taking into consideration other income of the cooperative (see in this respect, among others, Art. 57.2 of Law 27/1999 on Cooperatives). This same law expressly states that advances are not considered salary (Art.80.4). The exception is represented by Law 11/2019 on Basque Cooperatives, which departs from the cooperative economic framework and is governed by the rules of trading companies (Art. 69.1).

14. And so the aforementioned 2018 Resolution seems to admit when it states that: "Since, in practice, workers falling into each of these broad categories may have a greater or lesser degree of authority and dependence, there is to some extent a continuum between dependent work and self-employed work". 
not take into account the specific nature of worker cooperatives, nor are they consistent with the ICA Declaration on Worker Cooperatives (2008). It should be remembered that, according to this, the relationship between the worker-member and their cooperative is not that of a wage-based dependent worker, nor that of an individual self-employed worker.

This lack of recognition is confirmed when one looks at what a worker cooperative is for the ILO, according to the Handbook on Cooperatives for use by Workers by Guy Tchami (2007). The handbook aims to provide essential information on what all those interested in the promotion and development of cooperatives should know about them. In relation to worker cooperatives, he says that their aim is to create jobs for their members, and distinguishes between two types: producer cooperatives (or worker-owned cooperatives SCOP), and labour cooperatives. Of the former, he says that members are both co-owners and employees of the cooperative, and of the latter, that members "sell their labour and skills to other enterprises" (Tchami, 2007:30): The term "labour cooperatives" is used to refer to those cooperatives that exist simply to provide labour to other enterprises (Lima, 2007): 601).

Neither of these two models reflect what an associated work cooperative is. The first because it requires a dual relationship as owner and worker, for which it is not necessary to set up a cooperative, because any company offers this possibility. The second model because it reflects a practice that is often prohibited by law and is certainly rejected by the ICA (2005) when it says that cooperatives cannot act as intermediaries in the provision of jobs. It is surprising that it is seen as characteristic of a cooperative that its members sell their labour, when one of the founding principles of the ILO denies that labour is a commodity: "Labour is not a commodity" (Declaration of Philadelphia, 1944).

We therefore understand that, in countries such as France or Italy, where cooperatives do not exist as a specific type of organisation and have to be set up as limited or public limited companies, they have to hire their members so that they can work in the cooperative. ${ }^{15}$. The status of shareholder or member does not give the right to work in such cases. This obliges the signing of two contracts, one of association and the other of employment, hence the double member-worker status, which poses so many legal problems (Hiez, 2018:94).

But in those countries where cooperatives do exist as a specific form of organisation, the principle of identity applies: you are a worker in the cooperative because you are a member. The right and duty to work is the first and foremost consequence of membership. It is not a question of confusing the two relationships, as has been said, but of applying one of the characteristics of these cooperatives, as defined by Buchez: "l'absorption du contrat du travail ou de louage de services par et dans le contrat d'association" (Espagne, 2001).

As we can see, not all so-called worker cooperatives operate as recommended by the ICA. And the ILO, which classifies an organisation dedicated to the placement of labour as a cooperative, does not recognise the associated work carried out in cooperatives.

15. See in Italy the Códice Civile (Art. 2519) and Legge 3 aprile 2001 No. 142 (Art. 1.3); and in France la Loi No. 78-763 du 19 juillet 1978 portant statut des sociétés coopératives de production (Arts. 3, 10 and 15). 


\section{The Charter of the Self-Managed Worker}

Precisely in order to assess to what extent the work carried out by the members of a worker cooperative is different from dependent work and self-employed work, and requires an appropriate legal framework, a research programme has been developed in recent years by European and Latin American researchers with a mainly legal background ${ }^{16}$ and linked to the AIDCMESS Association ${ }^{17}$. One of the outcomes of this project was the Self-Managed Workers Charter published in $2018^{18}$. This study recognises the difficulty that a large part of legal academic opinion (mainly labour) and partly ILO, have in accepting associated work as different from dependent work and self-employed work ${ }^{19}$.

The Charter begins by analysing why associated work (also recognised as self-management) is neither dependent work nor self-employed work, and then goes on to propose a regulation that is coherent with its specific nature. According to it, associated work is not self-employed work because the members of the cooperative do not work independently, nor do they interact in their own name with clients; and it is not dependent or subordinate work because the workers are the owners of the enterprise and those who run it, directly or through the persons they have chosen to take over the management, in which case, their right/duty to manage is transformed into a right/duty to control of the management.

The Charter incorporates minimum requirements that it considers necessary to guarantee the dignity of associated work ${ }^{20}$, such as maximum working hours per day, weekly paid rest, minimum advances on account of results for the work performed, extra pay for night work, dangerous or unhealthy work, and other measures on health and safety at work, social insurance and accident insurance.

16. Research Programme Legal and social status of workers - members of cooperatives and other organisations of the Social and Solidarity Economy.

17. International Association of Cooperative, Mutual and Social and Solidarity Economy Law, based at the time at the National University of Rosario (Argentina).

18. The Charter of the Self-Managed Worker. Schujman, M (compiler). UNR Editora, National University of Rosario, 2018. Available at: http://www.ecosocial2020.es/wp-content/uploads/carta-del-trabajador-autogestionario.pdf. A text had previously been published in 2015 under the title of Worker Cooperatives in Latin America, which analysed the subject in the legislation, case law and legal academic opinion of various Latin American countries (Argentina, Brazil, Colombia, Costa Rica, Cuba, Ecuador, Mexico, Paraguay and Venezuela). Available at: https://rephip.unr.edu.ar/bitstream/handle/2133/18576/Las\%20Cooperativas\%20de\%20Trabajo\%20en\%20 America\%20Latina.pdf?sequence=3\&isAllowed $=y$

19. This critique is quite widespread in legal academic opinion (Henrÿ 2016:34).

20. The ILO definition of decent work is shared: "Decent work encapsulates the aspirations of people during their working lives. It means the opportunity to access productive employment that generates a fair income, security in the workplace and social protection for families, better prospects for personal development and social integration, freedom for individuals to express their views, organise and participate in the decisions that affect their lives, and equality of opportunity and treatment for all, women and men." (http://www.oit.org/global/topics/decent-work/ lang--es/index.htm). 
It is recognised that the relationship between the member and the cooperative is of an associative nature and is incompatible with contracts of a labour, civil or commercial nature, and must be regulated by the provisions of its by-laws, regulations and corporate resolutions, adopted by consensus of the members. To this end, the Charter outlines the issues that should be regulated in the Working Regulations, including guidelines for determining pay, working hours, leave, penalties, social security contributions, pension schemes, etc.

\section{Associative or Contractual Relationship?}

As we can see, both the ICA Declaration on Worker Cooperatives and the Self-Managed Workers Charter stress the importance of recognising that the relationship linking worker-members to their cooperative is an associative relationship and not an employment or business relationship.

In the same vein, the Framework Law on Cooperatives in Latin America (2009), after defining what an associated work cooperative is, establishes that "labour relations and compensation systems shall be regulated in accordance with the by-laws or special regulations approved by the cooperative's Members' General Meeting and shall not be subject to the labour legislation applicable to wage-based dependent workers. However, they must comply with social security and occupational risk protection standards, guaranteeing decent work for the members. This regulation, as the text itself states, is intended to prevent the Board of Directors from making decisions on matters which, because of their importance, should be taken by the cooperative's Members' General Meeting. The Framework Law includes much of the legislation on cooperatives in the countries of the continent, and above all what are considered the best provisions ${ }^{21}$.

This is also the situation in Spain, where legislation identifies an associated work cooperative as a cooperative whose purpose is to provide its members with jobs through their personal and direct effort, by means of the joint organisation of the production of goods or services for the market; and it describes the relationship between the member and the cooperative as being both corporate and self-managed ${ }^{22}$. Despite this recognition of self-regulation, cooperative legislation extends the rules on occupational health, occupational risk prevention and social security contributions to cooperatives (as self-employed or assimilated as dependent workers, as agreed in the by-laws). It also establishes the right of worker-members to periodically receive payments on account of surpluses, which will not be considered as a salary (Art. 80.4 CL); and although disputes arising from the provision of work are subject to the labour courts, the judges must resolve them by applying the cooperative law, the by-laws and internal rules of

21. More extensively on the regulation of cooperatives in various continents in the International Handbook of Cooperative Law, ed by Dante Cracogna, Antonio Fici and Hagen Henrÿ, Heildelberg, Springer, 2013.

22. Art. 80, paragraphs 1 and 5 of the Cooperatives Law 27/1999 (hereinafter referred to as CL). 
the cooperatives, the resolutions validly adopted by the corporate bodies and the cooperative principles (Art. $87 \mathrm{CL}$ ), and not labour legislation. Finally, cooperative legislation sets some limits to self-management, and refers to the provisions to be established by the members in certain matters, while respecting the minimum requirements imposed by cooperative legislation. In Spain, labour legislation is not applicable to the relationship between the cooperative and its worker-members and this has also been recognised by the Supreme Court, for whom this relationship is not an employment relationship, nor is there a dual corporate-labour relationship, even if the worker-member is made to sign an employment contract (Supreme Court Judgment 13.07.2009, App. No. 3554/2008 and 23.10.2009, App. No. 822/2009) ${ }^{23}$. In Portugal, worker-members of the cooperative also have the capacity to self-regulate their activity, although in practice they self-impose the same conditions that apply to wage-based workers (Meira, 2015): 273).

\section{The fraudulent use of worker cooperatives sometimes does not justify their non-recognition or prohibition}

Worker cooperatives are not only not recognised by the institutions, as we have seen, but are sometimes harshly attacked and even banned by governments ${ }^{24}$.

The reasons often cited for this lack of recognition are the modest size of these organisations and the abuse that is sometimes directed towards these cooperatives due to their not respecting labour regulations (Henrÿ, 2016): 34).

As for the modest size of these organisations, this is not a characteristic that can be generalised. There are large worker cooperatives with many worker-members and economic potential (Perotin, 2015) and there are small cooperatives developed both by unemployed workers and by professionals even in cutting-edge sectors such as health or new technologies. In general, most companies start with few employees and a small amount of equity capital, unless they originate from the conversion of other large companies. Nor is size a guarantee either of better service to consumers or of better conditions for workers. In fact, it is often noted that

23. As an exception, recently, the Supreme Court, in its Social Chamber, Judgment of May 8, 2019 declares that the worker members of the worker cooperatives have the right to join the union of their choice and the union has the right to exercise union action in defence of rights and interests of its members in this type of cooperatives (García Jiménez, 2020).

24. In this sense, the experience of Colombia in the period 2011-2014 (H. Zabala, 2015) or Brazil, in the years prior to the approval of Law 12.690/2012 on worker cooperatives (Lima, 2007, Marinho \& Pereira, 2012) can be pointed out. 
in larger cooperatives, member participation is lower than in smaller cooperatives, and there is a deterioration of internal democracy and working conditions for cooperative members and employees (Sachetto \& Semenzin, 2015).

As for the possibility that worker cooperatives can be used to circumvent the application of labour law, as the report Cooperatives and Employment: A Global Report points out ${ }^{25}$, this possibility exists and is unfortunately real, especially in certain sectors. However, this does not justify the opposition to worker cooperatives. The problem is not the legal structure but the abuse of it, and this must be tackled with increased training, information and control, for which the Public Administration bears part of the responsibility. Cooperative federations can also play an important role in ensuring the cooperative identity and its regular functioning $(\mathrm{H}$. Münkner, 2017).

The advantages of these cooperatives outweigh the potential risks.

On the one hand, worker cooperatives contribute to increasing employment by creating stable jobs with good conditions. As Hyungsik Eum pointed out "cooperative employment tends to be more sustainable over time, to suffer less income inequality, to be characterised by a better distribution between rural and urban areas, and to enjoy a higher level of job satisfaction and self-identity than average", adding "In worker cooperatives, worker-members have a sense of ownership of their own jobs and workplaces". ${ }^{26}$ Precisely because they own their enterprise, they have a greater interest in its long-term success, and this has been the main reason given as to why cooperatives are more resilient in periods of crisis such as the present (Sabín, Fernández and Bandrés, 2013; Bouchard, Le Guernic; Rousselière, 2020:5).

\section{Conclusions}

The ILO Recommendation of 2002 calls for the promotion of cooperatives and recommends a legal framework to governments favourable to cooperatives that is compatible with their nature and favours their autonomy and self-management.

Cooperatives are not recognised in all States, nor can they be said to have a legal framework generally compatible with their nature. Some countries have provided cooperatives with a specific legal framework and even their own organisational model.

One type of cooperative is a cooperative formed by people who pool their labour to produce goods or services for the market and share the profits generated. This is what is known as a worker cooperative, or associated work cooperative.

In a 2005 Declaration, the ICA established the characteristics of worker cooperatives, and

25. Report prepared by Bruno Roelants, Eum Hyungsik and Elisa Terrasi and published by CICOPA in 2014. http:// www.relats.org/documentos/ESS.CICOPA2.pdf

26. https://www.ica.coop/es/medios/noticias/entrevista-hyungsik-eum-autor-segundo-informe-global-cooperativas-empleo 
recommended some standards to be taken into account in their operation. Among other things, it pointed out that the relationship of the worker-member with their cooperative should be considered as distinct from that of the wage-based dependent worker and the self-employed individual. It recommended that they should not be used as instruments to make the working conditions of workers more precarious, nor to act as intermediaries in the provision of jobs.

Despite this, in the 2018 IL0 Guidelines on Cooperative Statistics, worker-members of cooperatives are classified as dependent workers, linked to the cooperative by an employment contract (employees) or as an employed contractor (dependent contractors).

While welcoming the ILO's efforts in attempting to count employment in the cooperative sector and recognising the difficulties involved in finding valid classification criteria at the international level, we are critical of the failure to recognise associated work as being inherent to the cooperative nature of work.

The contractual relationship between cooperatives and their worker-members makes sense in those cooperatives structured as limited or public limited companies, as is the case in France or Italy, because the corporate relationship does not give them the right to work. In those countries which, on the contrary, they have designed a specific legal structure for the cooperative, there is no need to contract the work of their members, because work is precisely the main right that one has as a member of the associated work cooperative.

The lack of recognition of worker cooperatives cannot be justified neither due to their modest size or by the possible abuse to which they may be subjected.

Worker cooperatives are an ideal instrument for generating decent employment and maintaining it even in times of crisis; they contribute to stabilising the labour market, to distributing wealth more equitably, and to strengthening democracy. The fight against fake cooperatives must be done by improving the training and information of their members, and the monitoring of cooperatives (García Jiménez, 2018; Fajardo, 2019).

\section{References}

ALEGRE, M. (2016): "La relación entre cooperativa de trabajo asociado y socio. Problemática planteada", En: G. Fajardo (dir.) y M.J. Senent (coord.), Cooperativas de Trabajo Asociado y Estatuto Jurídico de sus socios trabajadores, Ed. Tirant lo Blanch, 265-292.

ÁLVAREZ, J.F., BOLÍVAR, W.E., TORRES, Y.J., MÚNERA, F.N., CELY, J.N., GARCÍA, A. \& MELGUIZO, M.C. (2010): Buenas Prácticas en Cooperativas de Trabajo Asociado en Colombia: Una revisión de casos, DanSocial y Universidad Cooperativa de Colombia.

BENGOETXEA, A. (2016): “La contribución de las cooperativas de trabajo asociado a la creación y mantenimiento de empleo". En: G. Fajardo (dir.) y M.J. Senent (coord.), Cooperativas de Trabajo Asociado y Estatuto Jurídico de sus socios trabajadores, Ed. Tirant lo Blanch, 123-140. 
BOUCHARD, M.J., LE GUERNIC, M. \& D. ROUSSELIÉRE, G. (2020): Statistics on Cooperatives: concepts, classification, work and economic contribution measurement, 0IT.

CANALDA CRIADO, S. (2019): "El fomento del empleo decente y sostenible en cooperativas y sociedades laborales", REVESCO, Revista de Estudios Cooperativos, 132, 77-96.

CRACOGNA, D. (2015): "La legislación cooperativa latinoamericana en el marco del Plan para una Década Cooperativa de la Alianza Cooperativa Internacional", REVESCO, Revista de Estudios Cooperativos, 117, 12-33.

ELERMAN, D. (1984): “Workers' Cooperatives: The Question of Legal Structure”. In: Worker Cooperatives in America, University of California Press.

ESCRIBANO, J. (2013): "Empleo de calidad y cooperativas de trabajo asociado: trabajadores por cuenta ajena y socios trabajadores", CIRIEC-España, Revista Jurídica de Economía Social y Cooperativa, 24.

ESPAGNE, F. (2001): Le statut legal des cooperatives ouvrieres de production (S.C.O.P) en France. http://www.cedias.org/index.php?lvl=notice_display\&id=38074.

EUM, H. (2017): Cooperatives and Employment. Second Global Report. Contribution of cooperatives to decent work in the changing world of work, CICOPA.

EUM, H. (2020): "Statistics on work and employment in cooperatives". In: Bouchard, M.J., Le Guernic, M. and D. Rousseliére (coords.), Statistics on Cooperatives: concepts, classification, work and economic contribution measurement, OIT.

EUM, H., CARINI, C. \& BOUCHARD, M.J. (2020): "Classification of cooperatives. A proposed Typology", In: Statistics on Cooperatives: concepts, classification, work and economic contribution measurement, 0IT.

FAJARDO, I.G. (2016): "Naturaleza jurídica de la relación entre la cooperativa de trabajo asociado y el socio-trabajador. Consecuencias". En: G. Fajardo (dir.) y M.J. Senent (coord.), Cooperativas de Trabajo Asociado y Estatuto Jurídico de sus socios trabajadores, Ed. Tirant lo Blanch, 229-264.

FAJARDO, I.G. (2018): "Proposals for better governance in worker cooperatives", International Journal of Cooperative Law, Issue I, 11-27.

FAJARDO, I.G. (2019): "Falsas cooperativas de trabajadores y medidas adoptadas por los poderes públicos en España para combatirlas". Working Paper CIRIEC International, 30.

FERNÁNDEZ DE LA GÁNDARA, L. (1986): "Las cooperativas de producción como estructura jurídica de una economía autogestionaria", Revista Valenciana d'estudis autonòmics, 5-6, 9-38. 
GARCÍA JIMÉNEZ, M. (2008): Autoempleo: Trabajo Asociado y Trabajo Autónomo, Tecnos.

GARCÍA JIMÉNEZ, M. (2018): "Falsas cooperativas, usos abusivos y derechos de los trabajadores. Análisis jurisprudencial y propuestas de actuación", CIRIEC-España, Revista Jurídica de Economía Social y Cooperativa, 33, 185-222.

GARCÍA JIMÉNEZ, M. (2020): “Derechos de sindicación y libertad sindical en las Cooperativas de Trabajo Asociado. Comentario a la Sentencia del Tribunal Supremo (Sala de lo Social), de 8 de mayo de 2019. Roj: 1944/2019", CIRIEC-España, Revista Jurídica de Economía Social y Cooperativa, 36, 423-443. DOI: 10.7203/CIRIEC-JUR.36.17542.

HENRŸ, H. (2013): Orientaciones para la legislación cooperativa, 2ª ed. Ginebra, Oficina Internacional del Trabajo (OIT).

HENRŸ, H. (2015): "Las cooperativas de trabajadores en el contexto internacional". En: G. Fajardo (coord.), Empresas gestionadas por sus trabajadores. Problemática jurídica y social, CIRIEC-España editorial, 29-36.

HENRŸ, H. (2016): "El derecho del trabajo y la autogestión cooperativa en el contexto internacional global". En: G. Fajardo (dir.) y M.J. Senent (coord.), Cooperativas de Trabajo Asociado y Estatuto Jurídico de sus socios trabajadores, Ed. Tirant lo Blanch, 33-47.

HIEZ, D. (2018-2019): Sociétés Coopératives. 2ª ed. Dalloz.

HOLYOAKE, G.J. (1900): The history of the Rochdale Pioneers, 10th ed. Swan Sonnenschein \& Co., Lim. New York.

LIMA, J.C. (2007): “Worker's Cooperatives in Brazil: Autonomy vs Precariousness", Economic and Industrial Democracy, 28 (4), 589-621.

LLANAS, E.V. (2015): Socio trabajador y Cooperativa de Trabajo Asociado, Laborum.

LÓPEZ RODRÍGUEZ, J. (2019): "The promotion of both decent and green jobs through cooperatives", Boletín de la Asociación Internacional de Derecho Cooperativo, 54, 115-129. DOI: http://dx.doi.org/10.18543/baidc-54-2019pp115-129.

LÓPEZ MORA, F. (2016): "Socios trabajadores de cooperativas y estatuto profesional. Revisión crítica y propuestas". En: G. Fajardo (dir) y M.J. Senent (coord.), Cooperativas de Trabajo Asociado y Estatuto Jurídico de sus socios trabajadores, Ed. Tirant lo Blanch, 315-326.

MARINHO, C. \& PEREIRA, S. (2012): "A nova Lei de cooperativas de trabalho no Brasil: Novidades, controversias e interrogaçoes", Economía Solidaria e Políticas Públicas, Mercado de Trabalho, 53. 
MEIRA, D. (2015): "O projeto de investigaçao portugués desenvuelto no ámbito do programa internacional Estatuto jurídico de los trabajadores-socios de cooperativas y otras organizaciones de la economía social y solidaria". En: G. Fajardo (coord.), Empresas gestionadas por sus trabajadores. Problemática jurídica y social, CIRIEC-España editorial, 265-275.

MERCADER, J.R. (2015): “El contrato de trabajo y el contrato de sociedad. Una larga historia de encuentros y desencuentros". En: A. Rojo y A.B. Campuzano (coords.), Estudios jurídicos en Memoria del Profesor Emilio Beltrán. Liber Amicorum, Tirant lo Blanch, 153-198.

MONZÓN, J.L. (1989): Las cooperativas de trabajo asociado en la literatura económica y en los hechos, Colección Tesis Doctorales. Ministerio de Trabajo y Seguridad Social de España.

MÜNKNER, H. (2015): "Revision of co-operative law as a reaction to the challenger of economic, social and technological changes", CIRIEC-España, Revista Jurídica de Economía Social y Cooperativa, 26,11-25.

MÜNKNER, H. (2017): “Cooperative Audit”. In: G. Fajardo; A. Fici; H.Henrÿ, D. Hiez; D. Meira; H. Münkner and I. Snaith (eds.), Principles of European Cooperative Law. Principles, Commentaries and National Reports, Intersentia, 97-118.

PEROTIN, W. (2015): "What Do We Really Know About Workers' Cooperatives?". In: T. Webster, L. Shaw \& R. Vorberg-Rugh (eds), Cooperation: A Business Model for the 21st Century, Manchester University Press.

POLO, A. (1942): "Misión y sentido de la nueva Ley de Cooperación", Revista de Derecho Privado, 302, 213-235.

ROELANTS, B., EUM, H. \& TERRASI, E. (2014): Cooperativas y Empleo: un informe mundial, Cicopa y Desjardins.

RODRÍGUEZ, A. (2020): “Cooperativa-centro especial de empleo como forma jurídica de empresa para la inserción laboral. Análisis a partir de un caso", CIRIEC-España, Revista Jurídica de Economía Social y Cooperativa, (36), 93-130.

SABÍN, F., FERNÁNDEZ, J.L. \& BANDRÉS, I. (2013): "Factor C: Factores de resistencia de las microempresas cooperativas frente a la crisis y recomendaciones para un fortalecimiento cooperativo del sector de lo social", Revista Vasca de Economía Social, 9, 75-100.

SACCHETTO, D. \& SEMENZIN, M. (2015): “Workers' Cooperatives in Italy between Solidarity and Autocratic Centralism". In: Ngai Pun, Ben Hok-bun Ku, Hairong Yan, Anita Koo (eds), Social Economy in China and the Word, Routledge.

SAPOVADIA, V. \& PATEL, A. (2013): “What Works for Worker's Cooperatives? An Empirical Research on Succes \& Failure of Indian Workers' Cooperatives", ILO Workshop, Geneva, Vol. 1,1. 
SCHUJMAN, M. (compilador) (2015): Las cooperativas de trabajo en América Latina. Programa de Investigación: "Estatuto jurídico y social de los trabajadores- socios de cooperativa y otras organizaciones de la Economía Social y Solidaria, Ediciones DelReves.

SCHUJMAN, M. (compilador) (2018): Carta del trabajador autogestionario, UNR Editora, Universidad Nacional de Rosario. http://www.ecosocial2020.es/wp-content/uploads/cartadel-trabajador-autogestionario.pdf.

TCHAMI, G. (2007): Handbook on Cooperatives for use by Workers' Organizations, (Geneva), International Labour Office. https://www.ilo.org/empent/Publications/WCMS_094046/lang-en/index.htm.

TORRES, F.J. (2016): "La regulación de las cooperativas de trabajo asociado en la legislación española". En: G. Fajardo (dir.) y M.J. Senent (coord.), Cooperativas de Trabajo Asociado y Estatuto Jurídico de sus socios trabajadores, Ed. Tirant lo Blanch, 169-182.

VALDÉS DAL-RE, F. (1975): Las cooperativas de producción. Un estudio sobre el trabajo asociado, Editorial Montecorvo, S.A.

VERGEZ, M. (1972): El socio industrial, Editorial Tecnos, Madrid.

ZABALA, H. (2015): "El cooperativismo de trabajo asociado de Colombia en el periodo crítico (2011-2014)". En: Las cooperativas de trabajo en América Latina. Programa de Investigación: "Estatuto jurídico y social de los trabajadores- socios de cooperativa y otras organizaciones de la Economía Social y Solidaria, Ediciones DelReves, 509-568. 